\title{
Food Safety and Trade: Winners and Losers in a Non-Harmonized World
}

\author{
John S. Wilson and Tsunehiro Otsuki
}

The World Bank

\begin{abstract}
Food safety and the trade-off between precaution and increased agricultural exports are at the forefront of policy debate. Moreover, how international standards are set for food safety, can have a profound effect on export prospects for the least developed countries. This study examines the impact of adopting international food safety standards and harmonization of standards on global food trade patterns. The paper estimates the effect of aflatoxin standards in 15 importing (4 developing) countries on exports from 31 (21 developing ) countries. We estimate that world exports would rise by $\$ 38.8$ billion if an international standard (Codex) were adopted, compared to the current divergent national standards in place.
\end{abstract}

- JEL Classifications: F14, Q17

- Key words: Agricultural trade, Sanitang and phytosanitang measures, Food safety, Aflatoxins, Healthrisks, Gravity model, Codex

\section{Introduction}

The need to understand more precisely how food safety regulations affect trade is being driven, to a great extent, as a function of challenges in meeting the Agreement on the Application of Sanitary and Phytosanitary Standards (the "SPS Agreement") of the World Trade Organization (WTO). The SPS Agreement sets general guidelines under which trade in agricultural products is conducted to ensure that standards are based on sound science, and does not arbitrarily

*Corresponding address: John S. Wilson and Tsunehiro Otsuki, The World Bank, 1818H Street, N.W., Washington, D.C 20433, USA, Tel: 202 473-8095, Fax: 202 522-1159, E-mail: totsuki@ worldbank.org (C)2003-Center for International Economics, Sejong Institution, All Rights Reserved. 
discriminate or restrict trade. The WTO rules do allow members to set domestic standards at any level they deem appropriate, however, governments are encouraged to use international standards-where they exist. The WTO disciplines suggest, therefore, that harmonization and equivalence are the preferred methods of ensuring non-discrimination. A fragmented system of unilateral action on food safety standards is counter to both general WTO principles, and economically inefficient due to high transaction costs for exporters and global consumers. Although there is only limited empirical data in this field, it is assumed that developing countries are most directly affected by a fragmented system in which firms must meet differing standards for multiple export markets.

In the food trade, the Codex Alimentarius Commission (Codex) plays a central role in setting internationally acceptable standards. While governments through Codex have made progress in crafting harmonized standards in some areas, through the Commission consensus on key international food safety standards is lacking while national standards proliferate. Since regulatory requirements and product standards are substantially different across countries, typically between developed and developing countries (World Bank, 2001), trade disputes in a nonharmonized system are inevitable. ${ }^{1}$ The rising number of notifications to the WTO from developed and developing countries about national sanitary and phytosanitary standards (a 26 percent increase from 1995 to 1998) reflects this fact. Understanding the trade impact of these differing standards, therefore, is of significant importance and an area of key public policy concern as options to expand trade in agricultural products are examined.

This paper analyzes how global trade patterns in selected food products will change when differing levels of aflatoxin B1 standard are assumed. Aflatoxins are a group of toxic substances that can contaminate certain foods. There is evidence that aflatoxin B1 contamination is linked to liver cancer. The analysis here extends Otsuki et al. (2001b) by broadening the country coverage from Africa to a global scope, and by explicitly examining how imports and exports differ under various regulatory scenarios. The paper examines trade among 15 importing (4

\footnotetext{
${ }^{1}$ One example of the widely different approach to standards and food safety among trading partners is the new European Union (EU) maximum allowable level of aflatoxins in cereals, dried and preserved fruits and nut imports. This regulation, set for implementation in April 2002, has generated concern among exporting countries, many of them developing countries. Among the countries expressing concerns over the new EU standards were Argentina, Australia, Brazil, Canada, Colombia, India, Indonesia, Malaysia, Mexico, the Philippines, Senegal, South Africa, Thailand, Turkey, Uruguay and the US (1998, CRC Press LLC).
} 
developing) countries and 31 (21 developing) exporting countries in the world. All of these countries are WTO members except for Russia, Kazakhstan, and Vietnam. These three countries are, however, observers.

The paper is organized as follows. Section II reviews the concepts and debates over food safety regulations in general in the world food trade. Section III reviews issues related to aflatoxin regulations and world food trade. Section IV develops the empirical methodology to estimate the effect of aflatoxin regulations on bilateral trade flows. Section V then reports the results, and Section VI concludes and discusses the policy implications.

\section{World Food Safety Regulations and Trade}

Food safety regulations are mandatory controls over the quality attributes of a final product, based on the potential effects on human health from food handling, preparation, or consumption (Hooker 1999). The growing prominence of food safety controls in the public policy debate is based on both scientific and economic grounds (Henson and Caswell 1999).

What about trade rules and food safety? The WTO Sanitary and Phytosanitary (SPS) Agreement disciplines play an important role in promoting harmonization of food safety standards. The Agreement was entered into force as part of the Uruguay Round Agreements in January, 1995. The overall goal of the Agreement is to ensure transparency and non-discrimination in how governments can apply food safety, animal, and plant health regulations. SPS measures also address issues relating to market failures involved with imperfect information on food safety that can arise when consumers cannot pay for desired levels of safety and/or producers fail to supply improved food safety (IATRC 2001).

Food safety measures may have different implications in terms of the welfare effects in different countries depending on the differences in risk perceptions, available market information, the incidence of risk in production, and traditional methods of food processing and preparation as noted by IATRC (2001). The benefits of food safety regulation are reductions in risks of morbidity and mortality associated with the consumption of contaminated food (Antle, 1999). The costs of food safety regulation include the cost of production, the compliance cost, the administrative cost borne by the taxpayers, and the deadweight loss associated with taxation (Antle).

Petrey and Johnson (1993), Ndayisenga and Kinsey (1994), and Thilmany and 
Barrett (1997) illustrate the case where food safety regulations impede trade. Thornsbury et al.(1997) estimated the total impact of technical barriers on U.S. exports of agricultural products, and it was $\$ 4,907$ million in 1996, or 90 percent of which was due to sanitary and phytosanitary measures. The impact of food safety measures was estimated to be around \$2,288 million.

According to Henson and Caswell (1999), several international standards organizations, such as Codex, the International Plant Protection Convention (IPPC), and the International Office of Epizotics (OIE) have attempted to harmonize food safety regulations. Codex has designed a food code, particularly to serve as a global food treaty that can promote and protect SPS standards. The WTO is a proponent of using this food code to resolve scientific disputes. According to Henson and Caswell (1999), there are two approaches through which national food safety regulations can be justified. First, is the adoption of international standards that are assumed to comply with the provision of SPS agreement. Second, is the assessment of the risks to human health, plants and animal life, as per food safety regulations.

\section{The Regulation of Aflatoxins}

The regulation of aflatoxins in food products has gained considerable attention in recent years. Aflatoxins are a group of structurally related toxic compounds that contaminate certain foods and have been associated with acute liver carcinogens in humans. The different types of poisonous aflatoxins found in food are B1, B2, G1 and G2 (UNDP-FAO, 2000). Aflatoxin B1 is the most toxic and common aflatoxin. It is generally present in corn and corn products, groundnuts and groundnut products, cottonseed milk, and tree nuts, e.g. Brazil nuts, pecans, pistachio nuts, and walnuts (FAO-WHO,1997). In 1997, a Joint FAO/WHO Expert Committee on Food Additives (JECFA) estimated that reducing the aflatoxin standard from $20 \mathrm{ppb}$ (part per billion) to $10 \mathrm{ppb}$ will decrease 2 cancer deaths a year per billion people.

In 1997, the European Commission (EC) proposed a harmonization of maximum acceptable level of aflatoxins in certain foodstuffs. The standard ranged from $4 \mathrm{ppb}$ in cereals, edible nuts, and dried fruit, to $10 \mathrm{ppb}$ for nuts that are subject to further processing. Henson et al. (2000) noted that the EC proposal had led to concern among food exporters about the new and more restrictive standards' effect on trade patterns. Several exporting countries feared losses in their exports 
as a result of the more restrictive standard. Countries such as Bolivia, Brazil, Peru, India, Argentina, Canada, Mexico, Uruguay, Australia, and Pakistan requested detailed risk assessments from the European Union used in designing the new standard. As a consequence of consultations with their trading partners about these concerns, the European Commission relaxed the proposed aflatoxin standard in cereals, dried fruits, and nuts.

The revised aflatoxin standard in groundnuts subject to further processing was set at $15 \mathrm{ppb}$ ( $8 \mathrm{ppb}$ for B1) and $10 \mathrm{ppb}$ ( $5 \mathrm{ppb}$ for B1) for other nuts and dried fruits subject to further processing. For cereals, dried fruits, and nuts intended for direct human consumption, the standard was much more stringent and was set at $4 \mathrm{ppb}$ ( 2 ppb for B1). ${ }^{2}$ The aflatoxin standards suggested by Codex is significantly more relaxed than the EU standards. While Codex does set a standard specifically for B1 group of aflatoxin, it assumes that 50-70 percent or around 7.5-10.5 ppb of the total aflatoxin level of $15 \mathrm{ppb}$ is caused by aflatoxin B1. The overall Codex standard, therefore, is approximately $9 \mathrm{ppb}$.

Otsuki et al. (2001b) find that the implementation of the new aflatoxin standard by the European Commission will have an adverse effect on African exports of cereals, dried fruits, and edible nuts to Europe. The results for 9 African and 15 European countries show that as the maximum allowable level of aflatoxin B1 is lowered by 1 percent, exports of cereals from Africa to Europe decreases by 1.1 percent and the drop is 0.43 percent for fruits, nuts and vegetables. Groundnuts are most significantly affected by aflatoxin standards with a 1.3 percent decrease in exports. Results suggest that the aflatoxin standards proposed by the European Commission are far more stringent than the guidelines set by Codex when considering reduced exports. The total loss of export revenue for the 9 African countries in the study is estimated to be US $\$ 400$ million under EU standards, compared to a gain of US $\$ 670$ million if standards were adopted according to Codex guidelines.

\section{An Econometric Model to Examine Trade and Food Safety Standards}

When a measure of stringency of standards is available, an econometric approach has an advantage in measuring the statistical relationship between standards and trade flow, without prior imposition of the sign of the effect. It is also useful for examining policy implications once the relationship is estimated.

${ }^{2}$ Otsuki, Wilson and Sewadeh (2001a) provide a more detailed discussion of aflatoxin standards. 
Swann et al. (1996), Blind and Jungmittag (1999), Moenius (2000), Otsuki et al. (2001a), and Otsuki et al. (2001b), employed an econometric model where trade flows were regressed on a proxy for standards along with other factors that promote or divert trade. Swann et al. and Blind and Jungmittag regressed import and export on the stock of standards. Using a gravity model, Moenius regressed bilateral trade flow on the stock of standards along with Gross National Product (GNP) and population, and geographical distance between variables countries.

A gravity model is used to explain bilateral trade flows using key economic variables that represent the size of a country's economy, such as Gross National Product (GNP) and population, and geographical distance between variable countries. When combined with data on food safety standards in importing countries, bilateral trade flow data allows analysis of how differing standards promote or limit trade between pairs of importing and exporting countries.

Following the models developed by Otsuki et al. (2001a, 2001b), a panel is formed, with respect to exporting countries whose unobserved characteristics that are exporting country specific, may cause systematic variation.

Our specification of gravity model is as follows:

$\operatorname{In} V_{i j}=b_{0}+b_{1} \operatorname{In} G N P P C_{i}+b_{2} \operatorname{In} G N P P C_{j}+b_{3} \operatorname{In} D I S T_{i j}+b_{4} \operatorname{In} S T_{i}+b_{5} D C O L+b_{6 E U}$ $+b_{7} D_{\text {asean }}+b_{8} D_{N A F T A}+b_{9} D_{M E R C O S U R}+\varepsilon_{i j}$

$V_{i j}$ denotes the value of trade from country $j$ to country $i$. It is obtained from the trade data of the United Nations Statistical Office. Products that are included in this analysis include wheat (SITC041), rice (SITC042), maize (SITC044), dried and preserved fruits (SITC052), and nuts (SITC05171 and 05172). We use data for the time period between 1995 and 1998. Parameter b's are coefficients, $\varepsilon_{i j}^{k}$ and is the error term that is assumed to be normally distributed with mean zero. GNPPC and $\mathrm{GNPPC}_{j}$ are real per-capita GNP of importing country $i$ and exporting country $j$ in 1995 U.S. dollars, respectively. Per-capita GNP is used instead of GNP in order to net the country wealth's potential effect on food safety regulation. This is particularly important in importing countries. In general, an importing country with greater wealth tends to demand regulatory policies that guarantee greater public food safety, resulting in a more stringent food safety standard. If the effect is present, then the estimated coefficient for standard can suffer from a downward bias. DIST is the geographical distance between country $i$ and $j$.

$S T_{i}$ is the maximum level of Aflatoxin B1 imposed on imports by the importing country, $i$. It is expressed as Aflatoxin B1 contamination in parts per billion, and is 
obtained from FAO survey of mycotoxin standards on food and feedstuffs in 1995 (FAO, 1995). Table 1 depicts the Aflatoxin B1 standards for the importing countries in our sample. A greater value of this variable implies a more lax regulation of Aflatoxin B1 contamination, and vice versa. If this standard is applied at the border, products with Aflatoxin B1 contamination equal to or below ST would successfully enter the importing country.

Products with Aflatoxin B1 contamination above ST are retained in the exporting country, or rejected at the importing country's border. In this respect, a country that exports food products to more than one country faces different aflatoxin standards. Positive trade flows in COMTRADE data recorded from country to country with different standards imply that countries export food products with differing levels of aflatoxin contamination. Under the fragmented system of standard setting, aflatoxin standards for food safety tend to be heterogeneous within a given exporting country (e.g. there are production and distribution channels that satisfy different aflatoxin standards). The standards of exporting countries, therefore, do not necessarily measure minimum level of aflatoxin contamination in their exports.

The coefficient for this variable in our gravity model generally implies changes in exports associated with an incremental change (relaxation or tightening) in ST. If this standard does limit trade, then this coefficient is

Table 1. Aflatoxin B1 Standards followed by the Importing Countries

\begin{tabular}{|l|c|c|}
\hline \multicolumn{1}{|c|}{ Importer } & Standards for cereals and dried fruits (ppb) & Standards for nuts (ppb) \\
\hline Australia & 2.5 & 7.5 \\
\hline Austria & 1 & 1 \\
\hline Brazil & 5 & 5 \\
\hline Canada & 7.5 & 7.5 \\
\hline France & 5 & 1 \\
\hline Germany & 2 & 2 \\
\hline India & 30 & 30 \\
\hline Israel & 5 & 5 \\
\hline Italy & 5 & 5 \\
\hline Japan & 10 & 10 \\
\hline Malaysia & 17.5 & 17.5 \\
\hline Nigeria & 20 & 20 \\
\hline Spain & 5 & 5 \\
\hline UK & 2 & 2 \\
\hline USA & 10 & 10 \\
\hline
\end{tabular}

Source: FAO (1995) 
expected to be positive.

A dummy variable for colonial ties is included in order to control the omitted variable effect of colonial ties on trade flow as used in Otsuki et al. (2001a, 2001b). It takes the value of one if a colonial tie exists between a given set of importing and exporting countries, and zero, otherwise. Dummy variables for the free trade area (FTA) are included for a similar reason, as preferential treatment of exporting countries in a FTA member is likely to have a trade-promoting effect (Soloaga and Winters, 1999). The terms $D_{E U}, D_{A S E A N}, D_{N A F T A}$ and $D_{M E R C O S U R}$ denote the dummies for European Union, ASEAN, NAFTA and MERCOSUR, respectively. Dummy variables for the year also are included in the model, in order to control for systematic differences across time.

The period covered by the estimation is part of the implementation period of the Uruguay Round Agreement on Agriculture (URAA), which requires substantial reduction of tariff barriers and other protection measures. The URAA required different commitment between developed and developing countries, with a 36 percent reduction over six years from 1995 in developed countries, a 24 percent reduction over ten years from 1995 in several developing countries, and no reduction in least developing countries. These requirements have likely affected the agricultural import flows. The effect of the URAA can be controlled by including the applied tariff rates in the right hand side of the estimation model. Data on the applied tariff rates are, however, generally unavailable, and the use of the bound tariff rates or Most Favoured Nation (MFN) rates instead will likely fail to correctly capture the levels of tariff protection as the difference of applied rates from the bound and MFN rates are significant, particularly in developing countries (ERS). Some of the dummy variables and fixed effects with respect to exporting countries, however, can control for the effect of the differing applied tariff rates to some extent. The FTA dummies are likely to reflect the General System of Preference (GSP) treatment of the FTA members, and time dummies can capture global change in applied tariff rates over time. Moreover, exporting country fixed effects can capture the potential omitted valuable effect of tariffs that cannot be accounted for by the FTA and time dummies.

\section{Results}

Separate regressions are run for three product groups, cereals, nut products and 
Table 2. Fixed-Effects Model Regression Results $($ Dependent Variable $=$ Log Value of Trade Flow $)$

\begin{tabular}{|c|c|c|c|}
\hline & Cereals & Nuts & $\begin{array}{c}\text { Dried/preserved } \\
\text { Fruits }\end{array}$ \\
\hline $\begin{array}{l}\text { Log of importer's } \\
\text { GNP per capita }\end{array}$ & $\begin{array}{c}0.25 * * * \\
(0.09)\end{array}$ & $\begin{array}{c}0.27 * * * \\
(0.09)\end{array}$ & $\begin{array}{c}0.77 * * * \\
(0.1)\end{array}$ \\
\hline $\begin{array}{l}\text { Log of exporter's } \\
\text { GNP per capita }\end{array}$ & $\begin{array}{c}0.99 * * \\
(0.48) \\
\end{array}$ & $\begin{array}{l}0.55 \\
(0.5) \\
\end{array}$ & $\begin{array}{c}2.90 * * * \\
(0.48) \\
\end{array}$ \\
\hline Log of distance & $\begin{array}{c}-1.66 * * * \\
(0.15)\end{array}$ & $\begin{array}{c}-1.08 * * * \\
(0.14)\end{array}$ & $\begin{array}{c}-1.10 * * * \\
(0.12)\end{array}$ \\
\hline Log of standard & $\begin{array}{c}1.12 * * * \\
(0.13)\end{array}$ & $\begin{array}{c}0.34 * * * \\
(0.11)\end{array}$ & $\begin{array}{c}0.09 \\
(0.11)\end{array}$ \\
\hline Colonial tie dummy & $\begin{array}{c}2.44 * * * \\
(0.92)\end{array}$ & $\begin{array}{c}1.84 * * * \\
(0.61)\end{array}$ & $\begin{array}{l}1.8 * * * \\
(0.51)\end{array}$ \\
\hline $\begin{array}{l}\text { Dummy for European } \\
\text { Union Member }\end{array}$ & $\begin{array}{l}2.75 * * * \\
(0.4)\end{array}$ & $\begin{array}{c}2.12 * * * \\
(0.38)\end{array}$ & $\begin{array}{c}1.04 * * * \\
(0.33)\end{array}$ \\
\hline $\begin{array}{l}\text { Dummy for Mercosur } \\
\text { Member }\end{array}$ & $\begin{array}{c}3.76^{* * *} \\
(0.85)\end{array}$ & $\begin{array}{l}-0.96 \\
(1.09)\end{array}$ & $\begin{array}{l}3.9 * * * \\
(0.97) \\
\end{array}$ \\
\hline $\begin{array}{l}\text { Dummy for Asean } \\
\text { Member }\end{array}$ & $\begin{array}{l}-1.93 \\
(1.34) \\
\end{array}$ & $\begin{array}{l}-0.35 \\
(1.17) \\
\end{array}$ & $\begin{array}{l}2.23^{* *} \\
(1.06) \\
\end{array}$ \\
\hline $\begin{array}{l}\text { Dummy for NAFTA } \\
\text { Member }\end{array}$ & $\begin{array}{c}-2.60 * * * \\
(0.78)\end{array}$ & $\begin{array}{l}0.70 \\
(0.7)\end{array}$ & $\begin{array}{l}1.03 * \\
(0.61)\end{array}$ \\
\hline $\begin{array}{l}\text { Time dummy for year } \\
96\end{array}$ & $\begin{array}{c}0.01 \\
(0.23)\end{array}$ & $\begin{array}{c}0.02 \\
(0.21)\end{array}$ & $\begin{array}{c}0.25 \\
(0.19)\end{array}$ \\
\hline $\begin{array}{l}\text { Time dummy for year } \\
97\end{array}$ & $\begin{array}{c}0.09 \\
(0.23)\end{array}$ & $\begin{array}{l}0.20 \\
(0.2)\end{array}$ & $\begin{array}{l}-0.25 \\
(0.19)\end{array}$ \\
\hline $\begin{array}{l}\text { Time dummy for year } \\
98\end{array}$ & $\begin{array}{c}0.19 \\
(0.23)\end{array}$ & $\begin{array}{c}0.03 \\
(0.21)\end{array}$ & $\begin{array}{c}-0.38 * \\
(0.19)\end{array}$ \\
\hline Adjusted R-squared & 0.555 & 0.517 & 0.546 \\
\hline Number of observations & 970 & 912 & 844 \\
\hline
\end{tabular}

Notes: $1 . *, * *$ and $* * *$ imply significance at the 10 percent, 5 percent and 1 percent levels under a twotailed test respectively.

2. Inside parentheses are standard errors.

dried and preserved fruits using an fixed-effects model. Results are reported in Table 2. ${ }^{3}$ The results generally support the conclusion that the gravity model is well suited to examine all product groups in the analysis. The coefficients for percapita GNP in importing countries are positive and significant for all of the product groups. The results for per-capita GNP in exporting countries are significant except the case of nuts. The coefficients for distance are negative and

\footnotetext{
${ }^{3}$ The results were examined for robustness of variances using WLS. The fixed-effects model result is found to be robust against heteroscedasticity of the standard error of the error term.
} 
are significant for all of the product groups.

We find that aflatoxin B1 standards in importing countries have a negative effect on trade flows in the cereals and nuts regression. The impact of the standard is insignificant in the dried and preserved fruits regression. The first two results are consistent with the findings in Otsuki et al. (2001b). When global trade is examined in cereals and nuts, we find that a more stringent standard tends to limit trade. The results for dried and preserved fruits indicate, however, that the negative effect of the aflatoxin standard cannot be generalized globally.

The EU dummy is found to be positive and significant for all of the product groups. The Mercosur dummy is found to be positive and significant for cereals and dried and preserved fruits, but is insignificant for cereals. The results for the other FTA dummies do not show a strong support for the trade-promoting effect of a FTA.

\section{Simulation Exercises Under Various Scenarios}

In this section, we predict how trade patterns change, as aflatoxin B1 standards are harmonized at varying levels. We make the following assumptions prior to conducting the simulation analysis. The first relates to the effect of an exporting country's standard on its exports. We do not have data on exporting country standards in all of the cases. Importing and exporting countries are treated independently, therefore, such that an assumed level of aflatoxin B1 standard of a country as an importer does not imply the level of maximum aflatoxin B1 contamination of its exports of the same product.

The fixed-effects model coefficient estimates on the standard variable are used to predict changes in trade flows associated with different levels of aflatoxin B1 standards. ${ }^{4}$ We assume that the predicted change in the trade flow between a pair of importing and exporting countries will not exceed 100 percent in absolute value. Figure 1 presents the simulated relationship between aflatoxin standards and total trade flows between the 31 exporting countries and 15 importing countries, assuming a global harmonization of that standard. The predicted level of trade flow under the Codex recommended standard is of particular policy interest. It is useful to compare the trade flows under the Codex standard to those under the pre-harmonization standards, and to determine whether the Codex standard is more stringent or lax than pre-harmonization standards as a whole. In order to obtain a single level of standard per product category that can represent the pre-harmonization stringency of standards, we computed a break-even level of

${ }^{4}$ See Otsuki et al (2001a) for a detailed description of the methodology. 
Figure 1. Estimated Relationship between Aflatoxin B1 Standards and Trade Flow

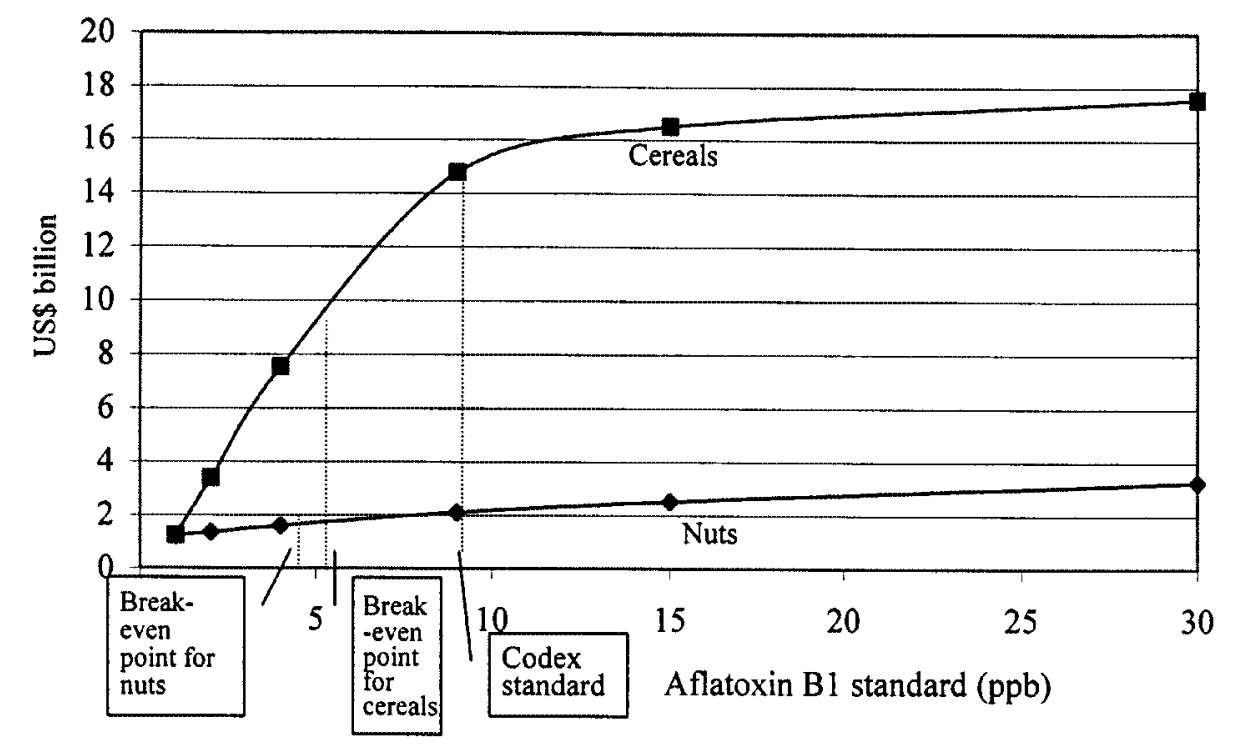

aflatoxin B1 standard for cereals and nuts, respectively, where a "break-even" point implies where the sums of losses and gains from a harmonized standard are equal within each product category. In what follows, this break-even point provides a zero-sum condition on the changes in the value of exports (or imports) across the exporting (or importing) countries. It is observed that the Codex standard at $9 \mathrm{ppb}$ being more lax than the standard at break even point (5.1 ppb for cereals and $4.1 \mathrm{ppb}$ for nuts), resulting in US\$ 5.6 billion (62 percent) and US\$ 473 million (17 percent) more trade flow, respectively, as long as the sum of trade flow from countries in our sample are concerned.

Moreover, the EU harmonization of aflatoxin B1 standards at 2 ppb for both product categories gives another case to be examined. It is possible to consider two cases. One is for only the EU member countries are assumed to harmonize at the 2 ppb level, whereas, as possible in the extreme situation, all nations are assumed to harmonize at that level.

Table 3 highlights the gains and losses for the trade flow of cereals and nuts relative to the pre-harmonization case. Case (1) corresponds to the preharmonization case. Case (2), (3) and (5) are based on harmonization of standard at break-even, Codex (9 ppb) and EU (2 ppb) levels, respectively. Case (4) is based on a partial harmonization where only the EU member countries harmonize at $2 \mathrm{ppb}$ leaving standards of the other importing countries unchanged. 
Table 3. Predicted Value of Trade Flow under Alternative Regulatory Cases by Product Category

(US\$ million)

\begin{tabular}{|c|c|c|c|c|c|c|c|c|c|}
\hline & \multicolumn{3}{|c|}{ Cereals } & \multicolumn{3}{|c|}{ Nuts } & \multicolumn{3}{|c|}{ Total } \\
\hline & Flow & $\begin{array}{c}\text { Change } \\
\text { (B) }\end{array}$ & $\mathrm{B} / \mathrm{A} \%$ & Flow & $\begin{array}{c}\text { Change } \\
\text { (D) }\end{array}$ & $\mathrm{D} / \mathrm{C} \%$ & Flow & $\begin{array}{c}\text { Change } \\
(\mathrm{F})\end{array}$ & $\mathrm{F} / \mathrm{E} \%$ \\
\hline $\begin{array}{l}\text { (1) Pre-harmoniza- } \\
\text { tion (no change) }\end{array}$ & $\begin{array}{r}(\mathrm{A}) \\
9,117\end{array}$ & 0 & 0 & $\begin{array}{r}(\mathrm{C}) \\
2,840\end{array}$ & 0 & 0 & $\begin{array}{r}(\mathrm{E}) \\
11,957\end{array}$ & 0 & 0 \\
\hline (2) Break-even point & 9,117 & 0 & 0 & 2,840 & 0 & 0 & 11,957 & 0 & 0 \\
\hline (3) Codex 9ppb & 14,783 & $+5,666$ & +62.1 & 3,313 & +473 & +16.7 & 18,096 & $+6,140$ & +51.3 \\
\hline $\begin{array}{l}\text { (4) Partial harmoniza- } \\
\text { tion at } 2 \text { ppba }\end{array}$ & 8,108 & $-1,009$ & -11.1 & 2,854 & +14 & +0.5 & 10,962 & -995 & -8.3 \\
\hline (5) All $2 \mathrm{ppb}$ & 3,382 & $-5,735$ & -62.9 & 2,524 & -315 & -11.1 & 5,906 & $-6,050$ & -50.6 \\
\hline
\end{tabular}

Note: anly the EU member countries harmonize at 2 ppb leaving standards of the other importing countries unchanged.

The total trade flow of cereals and nuts will increase by US\$ 6.1 billion under the Codex standard compared to that under the pre-harmonization case. On the other hand, the stringency of EU standard at 2 ppb reduces the trade flow by US \$ 6.1 billion. The loss in trade flow is significantly less (US\$ 995 million) when only EU harmonizes at $2 \mathrm{ppb}$ while the rest of the countries maintain their preharmonization level i.e. standards remain unchanged from the 1998 level.

Further scrutiny of these implication of alternative regulatory cases is made by disaggregating the prediction results by exporting countries. The trade flow estimates for each exporting countries under the five cases are reported in Table 4. We then investigate gains and losses from one alternative case relative to another by exporting countries. We consider the following five scenarios, Scenario One to Five. The result for each scenario is depicted in the corresponding column in Table 5.

Scenario One: The first scenario compares Case (4)-partial harmonization at 2 ppb-to Case (1)-pre-harmonization. This comparison shows how trade will change after Europe implements its new standard in 2002 for 31 exporting countries. The value of exports under Case (4) is found to be US $\$ 1.0$ billion (8.3 percent) less compared to the Case (1). Hungary, Israel and Brazil are found to be gainers from the EU harmonized standard. Their largest trading partner of cereals and nuts is Austria, which had a $1 \mathrm{ppb}$ standard prior to the harmonization. The other importing countries in the exercise are all expected to decrease exports .

Scenario Two: The second scenario compares Case (5)-all nations at $2 \mathrm{ppb}$ and Case (4)-partial harmonization at $2 \mathrm{ppb}$. As shown in Table 5 the value of exports under Case (5) is US\$ 5.1 billion (46 percent) lower when compared to Case (4). 
Table 4. Predicted Value of Trade Flow under Alternative Regulatory Cases by Exporting Country

(US\$ million)

\begin{tabular}{|l|r|r|r|r|r|}
\hline & $\begin{array}{c}\text { (1) Pre-harmoniza- } \\
\text { tion (no change) }\end{array}$ & $\begin{array}{c}\text { Break-even } \\
\text { Point }\end{array}$ & $\begin{array}{c}\text { (3) Codex 9 } \\
\text { ppb }\end{array}$ & $\begin{array}{c}\text { (4) Partial } \\
\text { harmoniza- } \\
\text { tion at 2 ppb }\end{array}$ & (5) All 2 ppb \\
\hline Argentina & 3858.8 & 3864.7 & 7162.0 & 3840.3 & 1253.3 \\
\hline Australia & 142.7 & 79.5 & 125.8 & 138.0 & 41.2 \\
\hline Austria & 30.8 & 38.4 & 58.4 & 15.9 & 15.5 \\
\hline Brazil & 26.2 & 28.2 & 33.2 & 26.3 & 23.5 \\
\hline Canada & 415.8 & 281.1 & 481.3 & 362.3 & 97.3 \\
\hline Denmark & 21.3 & 29.8 & 40.9 & 13.1 & 12.9 \\
\hline Egypt & 2.6 & 2.8 & 3.9 & 2.6 & 1.8 \\
\hline France & 1261.8 & 2124.5 & 2458.9 & 1020.7 & 1012.0 \\
\hline Germany & 363.3 & 434.2 & 678.5 & 192.1 & 190.2 \\
\hline Hungary & 46.7 & 66.2 & 85.0 & 51.8 & 46.6 \\
\hline India & 188.0 & 193.9 & 241.7 & 184.9 & 142.2 \\
\hline Israel & 7.2 & 8.6 & 10.1 & 7.3 & 6.9 \\
\hline Italy & 439.4 & 566.3 & 806.8 & 290.3 & 282.2 \\
\hline Kazakhstan & 15.7 & 15.2 & 22.3 & 13.5 & 7.9 \\
\hline Mexico & 4.9 & 4.3 & 5.6 & 4.6 & 3.1 \\
\hline Netherlands & 166.0 & 251.0 & 317.5 & 121.9 & 121.4 \\
\hline Nigeria & 1.7 & 2.0 & 2.6 & 1.5 & 1.1 \\
\hline Pakistan & 96.1 & 21.4 & 39.5 & 94.8 & 9.6 \\
\hline Paraguay & 37.4 & 37.7 & 70.1 & 37.3 & 12.2 \\
\hline Romania & 8.2 & 8.8 & 13.3 & 6.6 & 4.5 \\
\hline Russia & 3.0 & 2.7 & 4.2 & 2.4 & 1.3 \\
\hline Senegal & 7.3 & 6.4 & 10.8 & 4.7 & 2.7 \\
\hline South Africa & 23.3 & 22.0 & 28.4 & 22.4 & 14.8 \\
\hline Spain & 128.9 & 164.4 & 226.3 & 99.1 & 97.3 \\
\hline Sri Lanka & 20.2 & 16.5 & 20.3 & 20.1 & 13.2 \\
\hline Tanzania & 5.9 & 6.2 & 7.5 & 5.8 & 5.0 \\
\hline Thailand & 646.5 & 226.4 & 420.9 & 623.8 & 63.8 \\
\hline Uruguay & 47.1 & 47.2 & 87.4 & 46.8 & 15.3 \\
\hline USA & 3901.7 & 3419.4 & 4602.5 & 3673.4 & 2394.1 \\
\hline Vietnam & 2.8 & 19.3 & 27.4 & 35.0 & 12.5 \\
\hline Zimbabwe & 2.3 & 3.2 & 2.6 & 1.1 \\
\hline Total & 11956.6 & 11956.6 & 18096.3 & 10962.0 & 5906.4 \\
\hline & & & & & \\
\hline
\end{tabular}

Note: ${ }^{b}$ See the footnote for Table 3.

This implies that trade becomes much more restricted when all importers adopt the EU harmonized standard.

While there is not an obvious pattern of distribution of gainers and losers in 
scenario one, scenario two shows a clear contrast in the difference between developed and developing countries. The global harmonization at 2 ppb generates more loss for non-OECD countries than OECD countries. This is because the change in standards in non-OECD importing countries is more drastic than that in OECD countries given standards are less stringent in non-OECD today. NonOECD countries that export primarily to other non-OECD countries tend to lose from a world wide harmonization of standards at $2 \mathrm{ppb}$.

Scenario Three: The third scenario compares Case (2)-a harmonization under a break-even point to Case (1)-pre-harmonization. As Table 4 indicates, the majority of non-OECD exporting countries are losers whereas OECD countries are primarily gainers in this scenario. The OECD member countries are estimated to gain by US\$ 536 million or 7.7 percent of the total exports from the OECD member countries in the sample. In contrast, the non-OECD countries are estimated to lose by US\$ 502 million or 10 percent of the total exports from the non OECD countries in the sample.

Scenario Four: The fourth scenario compares Case (3)-Codex standard at $9 \mathrm{ppb}$ to Case (1)-pre-harmonization. Harmonization at the Codex level is estimated to increase the value of cereal and nut exports by US\$ 6.1 billion or 51 percent of the pre-harmonization level. Table 5 indicates that the value of exports under the Case (3) generates US\$ 6.0 billion more than the Case (1). In this scenario the EU countries e.g. France, Denmark and the Netherlands gain as a result of Codex standard. This is because these countries trade with other EU countries such as Germany and U.K which have relatively stringent standard currently. When the standards are relaxed to the Codex standard at $9 \mathrm{ppb}$, these countries experience an increase in trade flows. In contrast, developing countries such as Pakistan, Vietnam and Thailand exhibit a trade loss as a consequence of adopting the Codex standard.

Scenario Five: The last scenario compares Case (5)-all nations at $2 \mathrm{ppb}$ and Case (3) Codex standard at 9 ppb. Table 5 suggest that harmonization at the $2 \mathrm{ppb}$ level across all the importing countries will result in US\$ 12.2 billion or 67 percent decrease in cereal and nut exports. Some of the losing exporters under Case (5) i.e. at $2 \mathrm{ppb}$ are Thailand, Uruguay and Paraguay.. As we expect when the standards reach the stringency level of $2 \mathrm{ppb}$ from the Codex standard, all the countries experience a loss in trade flows.

Combined with the result in Table 5, Case (3) in this scenario will result in \$US 7.1 billion (64 percent) more exports than the case where only EU harmonizes 
Table 5. Comparison of Regulatory Cases by Exporting Country

\begin{tabular}{|c|c|c|c|c|c|}
\hline & Scenario 1 & Scenario 2 & Scenario 3 & Scenario 4 & Scenario 5 \\
\hline & (4) - & $(5)-(4)$ & (2) - & (3) & (3) \\
\hline & $(\$$ mil $) \quad(\%)$ & $(\$ \mathrm{mil}) \quad(\%)$ & $(\$$ mil $) \quad(\%)$ & $(\$ \mathrm{mil}) \quad(\%)$ & $(\$$ mil $)$ \\
\hline Argentina & $-18.5(-0.5)$ & $-2,587.0(-67.4)$ & $+5.9(+0.2)$ & $+3,303.2(+85.6)$ & $-5,908.7(-82.5)$ \\
\hline ustralia & $-4.7(-3.3)$ & $-96.8(-70.1)$ & $-63.2(-44.3)$ & $-16.9(-11.8)$ & $-84.6(-67.2)$ \\
\hline Austria & $-15.0(-48.5)$ & $-0.3(-2.2)$ & $+7.6(+24.6)$ & $+27.6(+89.5)$ & $-42.9(-73.4)$ \\
\hline 3razil & $+0.04(+0.2)$ & $-2.7(-10.4)$ & $+1.9(+7.4)$ & $+6.9(+26.4)$ & $-9.6(-29.0)$ \\
\hline Canada & $-53.5(-12.9)$ & $-264.9(-73.1)$ & $-134.7(-32.4)$ & $+65.5(+15.8)$ & $-384.0(-79.8)$ \\
\hline Denmark & $-8.2(-38.5)$ & $-0.3(-2.1)$ & $+8.4(+39.5)$ & $+19.5(+91.6)$ & $-28.0(-68.6)$ \\
\hline Egypt & $-0.1(-2.0)$ & $-0.8(-29.0)$ & $+0.2(+7.1)$ & $+1.3(+49.0)$ & $2.1(-53.3)$ \\
\hline France & $241.2(-19.1)$ & $-8.6(-0.8)$ & $+862.7(+68.4)$ & $+1,197.0(+94.9)$ & $-1,446.8(-58.8)$ \\
\hline Germany & $171.1(-47.1)$ & $-1.9(-1.0)$ & $+70.9(+19.5)$ & $+315.3(+86.8)$ & $-488.3(-72.0)$ \\
\hline Hungary & $+5.1(+10.9)$ & $-5.2(-10.1)$ & $+19.5(+41.7)$ & $+38.3(+81.9)$ & $-38.4(-45.2)$ \\
\hline India & $-3.1(-1.6)$ & $-42.7(-23.1)$ & $+5.9(+3.1)$ & $+53.7(+28.5)$ & $99.5(-41.2)$ \\
\hline Israel & $+0.1(+1.2)$ & $-0.4(-5.0)$ & $+1.4(+19.2)$ & $+2.9(+41.1)$ & $3.2(-31.9)$ \\
\hline Italy & $\mid 49.1(-33.9)$ & $-8.2(-2.8)$ & $+126.9(+28.9)$ & $+367.4(+83.6)$ & $-524.6(-65.0)$ \\
\hline $\begin{array}{l}\text { azakh- } \\
\text { an }\end{array}$ & $-2.3(-14.4)$ & $-5.5(-41.2)$ & $-0.6(-3.6)$ & $+6.6(+42.0)$ & $14.4(-64.5)$ \\
\hline Mexico & $-0.3(-5.2)$ & $-1.5(-33.2)$ & $-0.6(-12.9)$ & $+0.7(+13.7)$ & $2.5(-44.4)$ \\
\hline $\begin{array}{l}\text { Nether- } \\
\text { lands }\end{array}$ & $-44.1(-26.6)$ & $-0.5(-0.4)$ & $+85.0(+51.2)$ & $+151.5(+91.3)$ & $-196.1(-61.8)$ \\
\hline Nigeria & $-0.2(-11.2)$ & $-0.4(-27.2)$ & $+0.3(+14.7)$ & $+0.9(+51.3)$ & $1.5(-57.3)$ \\
\hline Pakistan & $-1.3(-1.3)$ & $-85.2(-89.9)$ & $-74.7(-77.8)$ & $-56.6(-58.9)$ & $-29.9(-75.7)$ \\
\hline Paraguay & $-0.1(-0.3)$ & $-25.1(-67.3)$ & $+0.4(+1.0)$ & $+32.7(+87.6)$ & $57.9(-82.6)$ \\
\hline Romania & $-1.6(-19.2)$ & $-2.1(-31.6)$ & $+0.6(+7.4)$ & $+5.1(+61.7)$ & $8.7(-65.8)$ \\
\hline Russia & $-0.5(-17.2)$ & $-1.2(-48.8)$ & $-0.2(-7.8)$ & $+1.2(+41.5)$ & $2.9(-70.0)$ \\
\hline Senega & $-2.5(-34.7)$ & $-2.0(-43.0)$ & $-0.9(-11.8)$ & $+3.5(+48.7)$ & $-8.1(-75.0)$ \\
\hline S. Africa & $-0.8(-3.6)$ & $-7.6(-34.1)$ & $-1.2(-5.3)$ & $+5.2(+22.2)$ & $-13.7(-48.0)$ \\
\hline Spain & $-29.8(-23.1)$ & $-1.8(-1.8)$ & $+35.4(+27.5)$ & $+97.4(+75.6)$ & $-129.0(-57.0)$ \\
\hline Sri Lanka & $-0.1(-0.5)$ & $-6.8(-34.0)$ & $-3.7(-18.1)$ & $+0.1(+0.6)$ & $-7.0(-34.7)$ \\
\hline Tanzania & $-0.03(-0.6)$ & $-0.9(-14.8)$ & $+0.4(+6.2)$ & $+1.7(+28.3)$ & $2.6(-34.0)$ \\
\hline Thailand & $-22.7(-3.5)$ & $-560.0(-89.8)$ & $-420.0(-65.0)$ & $-225.6(-34.9)$ & $-357.1(-84.9)$ \\
\hline Uruguay & $-0.2(-0.5)$ & $-31.6(-67.4)$ & $+0.1(+0.2)$ & $+40.4(+85.8)$ & $-72.1(-82.5)$ \\
\hline USA & $-228.3(-5.9)$ & $-1,279.3(-34.8)$ & $-482.4(-12.4)$ & $+700.8(+18.0)$ & $-2,208.4(-48.0)$ \\
\hline Vietnam & $-0.4(-1.1)$ & $-22.5(-64.2)$ & $-16.1(-45.6)$ & $-8.0(-22.7)$ & $-14.8(-54.2)$ \\
\hline $\begin{array}{l}\text { Zimba- } \\
\text { bwe }\end{array}$ & $-0.2(-7.4)$ & $-1.5(-59.2)$ & $-0.6(-19.6)$ & $+0.4(+14.0)$ & $-2.1(-66.9)$ \\
\hline Total & $-9,94.6(-8.3)$ & $-50,55.6(-46.1)$ & $0.0(0.0)$ & $+6,139.6(+51.3)$ & $\begin{array}{r}-12,189.8(- \\
67.4)\end{array}$ \\
\hline
\end{tabular}

Note: 'This means trade flow under Case (4) minus that under Case (1). See Table 4 for corresponding trade flow estimates.

standard at $2 \mathrm{ppb}$ leaving other importing countries unchanged their standards. 
In sum, the country-level analysis indicates that the value of exports from EU countries are relatively unaffected by the EU harmonized standard whereas developing countries are mostly losers from the harmonization.

In the final simulation, changes in value of trade flow are computed for each importing and exporting country. The trading partner within the sample countries which account for the largest gain and loss of trade flow is then identified.

Table 6 presents the result for importing countries. The highest gain is experienced by U.K. with an estimated increase of US $\$ 719$ thousand, accounting for 45 percent of the total positive change in trade flow. Countries that increase imports from the harmonization at the break-even point level are UK, Germany, Austria, Brazil, France, Australia, Spain, Italy and Israel. However, among them three EU countries UK, Germany and Austria constitute for more than 90 percent of the gains. This reinstates the fact that EU countries have had the most stringent standard in the world and hence, they are better off when standards are relaxed to 5.1 for cereals and 4.7 for nuts at the break even point. France is the major exporting partner to most of the EU importing countries. The harmonization thus

Table 6. Predicted Change in Imports at the Break-Even Point

\begin{tabular}{|l|r|r|r|l|r|r|r|}
\hline Importer & $\begin{array}{c}\text { Change } \\
\text { (US\$ } \\
1,000)\end{array}$ & $\begin{array}{c}\text { Share in } \\
\text { total posi- } \\
\text { tive (nega- } \\
\text { tive) } \\
\text { change in } \\
\text { percent }\end{array}$ & $\begin{array}{c}\text { Change } \\
\text { (\%) in } \\
\text { country's } \\
\text { export }\end{array}$ & $\begin{array}{c}\text { Partner } \\
\text { whose } \\
\text { trade flow } \\
\text { will } \\
\text { increase } \\
\text { most }\end{array}$ & $\begin{array}{c}\text { Change } \\
\text { (US\$ } \\
1,000)\end{array}$ & $\begin{array}{c}\text { Partner } \\
\text { whose } \\
\text { trade flow } \\
\text { will } \\
\text { decrease } \\
\text { most }\end{array}$ & $\begin{array}{c}\text { Change } \\
\text { (US\$ } \\
1,000)\end{array}$ \\
\hline UK & $+718,725$ & +45 & +91 & France & $+462,788$ & & \\
\hline Germany & $+642,428$ & +40.2 & +93 & France & $+394,212$ & & \\
\hline Austria & $+93,678$ & +5.9 & +100 & USA & $+40,773$ & & \\
\hline Brazil & $+74,081$ & +4.6 & +2 & Argentina & $+71,104$ & India & -38 \\
\hline France & $+33,577$ & +2.1 & +4 & USA & $+9,111$ & & \\
\hline Australia & $+18,859$ & +1.2 & +33 & Thailand & $+8,608$ & India & $-1,851$ \\
\hline Spain & $+7,943$ & +0.5 & +1 & France & $+3,489$ & India & -99 \\
\hline Italy & $+6,874$ & +0.4 & +1 & France & $+3,403$ & India & -125 \\
\hline Israel & $+1,554$ & +0.1 & +1 & USA & +770 & India & -159 \\
\hline USA & $-132,257$ & -8.3 & -52 & & & Canada & $-91,800$ \\
\hline Nigeria & $-170,477$ & -10.7 & -78 & & & USA & $-98,833$ \\
\hline Japan & $-190,853$ & -11.9 & -49 & & & USA & $-80,737$ \\
\hline Malaysia & $-283,674$ & -17.8 & -73 & & & Thailand & $-125,267$ \\
\hline Canada & $-325,236$ & -20.4 & -22 & & & USA & $-307,920$ \\
\hline India & $-495,190$ & -31 & -91 & & & Thailand & $-231,528$ \\
\hline
\end{tabular}


will tend to increase intra-regional trade in EU or industrialized countries in general. India suffers the biggest loss in imports, with Thailand as its trading partner whose trade flow will decrease the most. This result confirms that India has the most lax standards ( $30 \mathrm{ppb})$ of all the importing countries in the sample.

Table 7 shows the result of the same exercise for the exporting countries. The result indicates that France increases exports accounting for 72 percent of the total positive gain. The six EU countries (France, Italy, Netherlands, Germany, Spain and Hungary) account for more than 95 percent of gains in exports. Their trading partners gaining from the harmonization are also EU countries, Germany, UK and Austria. This also confirms that the harmonization at the break-even point will greatly increase intra-EU trade. It should be noted that the trading partners (i.e. the importers) of the gainers are the countries with very stringent aflatoxin standard. Hence it is obvious that harmonization at the break even point benefits the six EU countries, the gains coming from countries moving to relatively lax standard from very stringent standard. On the other hand, most developing countries lose exports as a result of harmonization. Countries like Canada, Mexico, Australia and Pakistan who feared losses due to the stringent standards set by EU ( 2 ppb), suffer a loss in exports even from harmonization at the break-even point. With stringent standard level at EU harmonization, some countries in Table 7 (e.g. Israel, Egypt) with very small gains are likely to lose. It is interesting to note that developing countries like India and Nigeria gain as exporters as a result of harmonization even though as importers they lose. This is due to the separation assumption for simulation-the change in the value of exports and imports of these countries are computed as though they were different countries. Hence, it is possible that India and Nigeria have the EU countries as their trading partners and hence, gain as exporters as a result of relaxation of standard in the EU due to harmonization. USA and Canada will also decrease their exports due to the contraction of mutual trade since their standards are more lax than the break-even level.

Simulation results in Table 7 shows that U.S. and Canada lose in exports as a consequence of harmonization at the break-even point. Authors' calculation based on the UN COMTRADE data records report that U.S. and Canada experienced a 5.6 percent decline in exports in the global market between 1995-1998. ${ }^{5}$ Hence, it is reasonable to assume that harmonization of aflatoxin standard in general (may be different from the break even point level) will adversely affect U.S. and Canada as exporters. However, the effect of harmonization on European Union countries

\footnotetext{
${ }^{5}$ Factors other than aflatoxin standard also affect this change in exports.
} 
Table 7. Predicted Change in Exports at the Break-even Point

\begin{tabular}{|c|c|c|c|c|c|c|c|}
\hline Exporter & $\begin{array}{c}\text { Change } \\
\text { (US\$ } \\
1,000)\end{array}$ & \begin{tabular}{|c|} 
Share in \\
total posi- \\
tive (nega- \\
tive) \\
change in \\
percent
\end{tabular} & $\begin{array}{l}\text { Change } \\
(\%) \text { in } \\
\text { country's } \\
\text { export }\end{array}$ & \begin{tabular}{|c} 
Partner \\
whose \\
trade flow \\
will \\
increase \\
most
\end{tabular} & $\begin{array}{c}\text { Change } \\
\text { (US\$ } \\
1,000)\end{array}$ & \begin{tabular}{|c|} 
Partner \\
whose \\
trade flow \\
will \\
decrease \\
most
\end{tabular} & $\begin{array}{c}\text { Change } \\
\text { (US\$ } \\
1,000 \text { ) }\end{array}$ \\
\hline France & $+861,288$ & \begin{tabular}{|c|}
+71.6 \\
\end{tabular} & +69 & UK & $+463,235$ & India & $-1,562$ \\
\hline Italy & $+120,195$ & +10.0 & +28 & Germany & $+71,352$ & India & $-1,482$ \\
\hline $\begin{array}{l}\text { The Neth- } \\
\text { erlands }\end{array}$ & $+84,559$ & +7.0 & +52 & Germany & $+57,252$ & India & -98 \\
\hline Germany & $+56,169$ & +4.7 & +17 & $\overline{\mathrm{UK}}$ & $+49,075$ & India & -343 \\
\hline Spain & $+27,681$ & +2.3 & +24 & UK & $+13,166$ & Nigeria & -326 \\
\hline Hungary & $+19,984$ & +1.7 & +42 & Austria & $+17,829$ & India & $-1,155$ \\
\hline India & $+8,828$ & +0.7 & +4 & UK & $+30,390$ & Malaysia & $-16,447$ \\
\hline Denmark & $+8,332$ & +0.7 & +40 & Germany & $+5,492$ & India & -61 \\
\hline Austria & $+7,490$ & +0.6 & +25 & Germany & $+5,279$ & India & -74 \\
\hline Argentina & $+5,542$ & +0.5 & 0 & Brazil & $+82,251$ & Nigeria & $-20,996$ \\
\hline Tanzania & $+2,118$ & +0.2 & +10 & UK & $+3,010$ & India & -419 \\
\hline Romania & +543 & +0.05 & +7 & Austria & +746 & India & -455 \\
\hline Paraguay & +367 & +0.03 & +1 & Brazil & +818 & USA & -137 \\
\hline Nigeria & +314 & +0.03 & +16 & UK & +458 & India & -97 \\
\hline Uruguay & +95 & +0.01 & 0 & Brazil & $+1,005$ & Nigeria & -255 \\
\hline Egypt & +51 & +0.01 & +4 & UK & +102 & India & -40 \\
\hline Israel & +34 & +0.01 & +8 & Austria & +42 & India & -17 \\
\hline Brazil & \begin{tabular}{|l|}
-189 \\
\end{tabular} & -0.02 & -1 & Austria & $+1,185$ & USA & -735 \\
\hline Russia & -239 & -0.02 & -8 & Germany & +204 & India & -368 \\
\hline Zimbabwe & -478 & -0.04 & -14 & UK & +533 & Nigeria & -404 \\
\hline Senegal & -643 & -0.05 & -6 & France & +397 & Nigeria & -867 \\
\hline Mexico & -729 & -0.06 & -16 & Germany & +101 & USA & -259 \\
\hline $\begin{array}{l}\text { Kazakh- } \\
\text { stan }\end{array}$ & -837 & -0.07 & -6 & Germany & $+1,023$ & India & $-1,694$ \\
\hline $\begin{array}{l}\text { South } \\
\text { Africa }\end{array}$ & $-2,188$ & -0.2 & -17 & UK & $+2,045$ & Nigeria & $-1,764$ \\
\hline Sri Lanka & $-5,163$ & -0.4 & -25 & Austria & +625 & India & $-2,706$ \\
\hline Vietnam & $-17,471$ & -1.5 & -49 & Austria & +468 & Malaysia & $-10,742$ \\
\hline Australia & $-64,675$ & -5.4 & -55 & Germany & $+1,309$ & Malaysia & $-28,509$ \\
\hline Pakistan & $-75,124$ & -6.2 & -83 & Germany & +385 & India & $-71,428$ \\
\hline Canada & $-134,549$ & -11.2 & -33 & UK & $+12,308$ & USA & $-91,532$ \\
\hline Thailand & $-419,924$ & -34.9 & -65 & Australia & $+8,614$ & India & 231,402 \\
\hline USA & $-481,349$ & -40 & -17 & UK & $+67,538$ & Canada & $-291,574$ \\
\hline
\end{tabular}

is imprecise. These countries experience a positive change in exports at the break- 
even point whereas UN Comtrade data records show that there is a downward trend of 3.2 percent in exports for these countries between 1995-1998. Hence, the net effect of harmonization is hard to predict. On the other hand, the Asian, African and Latin American countries are found to have a positive trend in exports for the period 1995-1998. This positive growth is as high as 27 percent for the Asian countries. Consider Vietnam, Thailand, Sri Lanka and Pakistan as representative of the Asian sector. These countries who are actually suffering a loss in exports at the break even point might turn out to be gainers due to harmonization if this loss is offset by the positive trend in exports. The African and Latin American countries in our sample exhibit both positive and negative change in trade flow at the break even point. Hence, the net effect of harmonized aflatoxin standards on these countries is unclear at this point.

\section{Conclusions}

This study examines the impact of adopting international food safety standards and harmonization of standards on global food trade patterns. The paper develops econometric models and a simulation method to estimate the effect of aflatoxin standards in 15 importing (4 developing) countries on exports from 31 (21 developing) countries.

The analysis extends Otsuki et al. (2001b) by broadening the country coverage from Africa to a global scope and by explicitly examining how imports and exports differ under various regulatory scenarios. Our analysis uses the first stage estimates of the elasticity of bilateral trade flows in certain foods with respect to the Aflatoxin B1 standard.

The findings support those in Otsuki et al. (2001b) which show that the value of trade in cereals and nuts is negatively affected by aflatoxin B1 standard and that this negative relationship is not apparent in the case of dried and preserved fruits trade.

The results in this analysis are combined to predict how the direction of trade is altered by food safety regulations under alternative scenarios. We find that adopting an international standard for aflatoxin B1 based on current Codex guidelines will increase cereal and nut trade among countries in the exercise by \$US 6.1 billion, or 51 percent from the pre-harmonization levels. It is \$US 12.2 billion or 67 percent more than the value of exports under the case where all 15 importing countries harmonize their standards at the $2 \mathrm{ppb}$ level. Moreover, we 
estimate that world exports would rise by \$US 38.8 billion if an international standard (Codex) were adopted, compared to the current divergent national standards in place. World exports are estimated to decrease by US\$ 3.1 billion if the world adopted the EU standard (i.e. 2 ppb) compared to current national standards.

Harmonization of this food safety standard at a level more stringent than one suggested by international standards indicates that food safety standards can severely limit developing country exports. This analysis reveals, moreover, the trade impact of a fragmented food safety system in which national regulations differ across trading partners. An initiative to encourage international standards, along with mechanisms to directly assist developing countries in raising standards to international levels merits serious consideration. In this specific case of aflatoxin standards, one might consider programs to provide vaccination against hepatitis B to lower risk of liver cancer (along with other serious health risks), encouraging the development of an international standard to be adopted worldwide, and aid to the least developed producers of agricultural commodities most affected by aflatoxin contaminations. ${ }^{6}$

\section{Acknowledgement}

The authors are grateful to an anonymous reviewer for useful comments. They are also grateful to Baishali Majumdar and Robert Simms for their assistance. The view and interpretations expressed in this paper are those of the authors and do not necessarily represent the view and policies of the World Bank.

Received 23 August 2001, Accepted 12 May 2002

\section{References}

Antle, John M. (1999). Benefits and Costs of Food Safety Regulation. Food Policy 24. 605-623.

Blind, K. and A. Jungmittag (1999). The impacts of innovations and standards and German trade in general and on trade with the UK in particular. Internal Paper of Fraunhofer 2, 205-221.

Committee on Sanitary and Phytosanitary Measures, World Trade Organization (1998).

${ }^{6}$ For details on conclusions by JECFA regarding aflatoxin standards and risk see; John L. Herrman, World Health Organization, World Trade Organization, Presentation at the Risk Assessment Workshop, June 19-20, 2000, http://www.wto.org/english/tratop_e/sps_e/risk00_e/risk00_e.htm\#programme. 
Submission by the Gambia. G/SPS/GEN/50, February 10, 1998. World Trade Organization, Geneva.

European Commission (1997). Commission Regulation (EC) No. 194/97 of 31 of January 1997, The European Commission.

European Commission (1998). Commission Regulation (EC) No. 1525/98 of 16 July 1998, The European Commission.

European Commission (2001). Commission Regulation (EC) No 466/2001 of 8 March 2001, The European Commission.

FAO/WHO (Food and Agriculture Organisation and World Health Organisation) (1997). Acceptable Daily Intakes, Other Txicological Information, and Information on Specifications. Joint FAO/WHO Expert Committee on Food Additives, Rome, 17-26 June 1997.

Food and Agriculture Organization (1995). Worldwide Regulations for Micotoxins 1995: A Compendium. FAO, Rome.

Hooker, Neal H. (1999). Food Safety Regulation and Trade in Food Products. Food Policy 24, 653-668.

Hooker, Neal H. and Caswell, Julie A. (1995). Regulatory Targets and Regimes for Food Safety: A Comparison of North American and European Approaches. Food Marketing Policy Center, Department of Agricultural and Resource Economics, University of Connecticut.

Henson, Spencer and Caswell, Julie A. (1999). Food Safety Regulation: An Overview of Contemporary Issues. Food Policy 24, 589-603.

Henson, Spencer; Loader, Rupert; Swinbank, Allan; Bredahl, Maury; and Lux, Nicole (2000). Impact of Sanitary and Phytosanitary Mesures on Developing Countries.

Center for Food Economics Research, University of Reading, Reading, UK.

Moenius, J. (2000). Three Essays on Trade Barriers and Trade Volumes. Ph.D. Dissertation. University of California, San Diego

Maskus, Keith. E. and John S. Wilson (2001). Technical Barriers to Trade: A Review of Past Attempts and the New Policy Context. In Maskus, K.E. and Wilson, J.S. (Eds.) Quantifying Trade Effect of Technical Barriers: Can it be done? University of Michigan Press, Ann Arbor, MI.

Maskus, Keith. E. and John S. Wilson, and Tsunehiro Otsuki (2001). An Empirical Framework for Analyzing Technical Regulations and Trade. In Maskus, K.E. and Wilson, J.S. (Eds.) Quantifying Trade Effect of Technical Barriers: Can it be done? University of Michigan Press, Ann Arbor, MI.

Ndayisenga, F., Kinsey, J., (1994). The Structure of Non-Tariff Trade Measures on Agricultural Products in High Income Countries. Agribusiness 10 (4), 275-292.

Orden, David and Donna Roberts (Eds.), 1997. Understanding Technical Barriers to Agriculture Trade, Proceedings of a Conference of the International Agricultural Trade Research Consortium, University of Minnesota, Department of Applied Economics, St. Paul, MN.

Otsuki, Tsunehiro, John S. Wilson, and Mirvat Sewadeh (2001a). What Price Precaution? 
European Harmonisation of Aflatoxin Regulations and African Groundnuts Exports. European Review of Agricultural Economics 28(2), 263-283.

Otsuki, Tsunehiro, John S. Wilson, and Mirvat Sewadeh (2001b). Saving Two in a Billion: Quantifying the Trade Effect of European Food Safety Standards on African exports. Food Policy 26, 495-514.

Petrey, L.A. and Johnson, R.W.M. (1993). Agriculture in the Uruguay Round: Sanitary and Phytosanitary Measures. Review of Marketing and Agricultural Economics 61, 433-442.

Roberts, D. and DeRemer, K. (1997). Technical Barriers to US Agricultural Exports. Economic Research Service, USDA, Washington, DC.

Soloaga, I. and L. A. Winters (1999). How Has Regionalism in the 1990s Affected Trade. World Bank Policy Research Working Paper \#2156. The World Bank. Washington, D.C.

Swann, P., P. Temple, and M. Shurmer (1996). Standards and trade performance: The UK experience. Economic Journal 106: 1297-1313.

The International Agricultural Trade Research Consortium (2001). The Role of Product Attributes in The Agricultural Negotiations, Commissioned Paper \# 17, May 2001.

Thilmany, D.D., Barrett, C.B. (1997). Regulatory Barriers in an Integrating World Food Market. Review of Agricultural Economics 19 (1), 91-107.

Thornsbury, S., Roberts, D., DeRemer, K., and Orden, D. (1997). A First Step in Understanding Technical Barriers to Agricultural Trade. Paper presented at the Conference of the International Association of Agricultural Economists, Sacramento, August 1997.

UNDP/FAO (1998). Regional Network Inter-Country Cooperation on Preharvest Technology and Quality Control of Food grains (REGNET) and the ASEAN Grain Postharvest Programme,Bangkok, Thailand. http://www.fao.org/inpho/vlibrary/ x0036e/x0036e00.htm.

U.S. Food and Drug Administration (2000). Foodborne Pathogenic Microorganisms and Natural Toxins Handbook. http://vm.cfsan.fda.gov/ mow/chap41.html

Wilson, John S. (2000). The Development Challenge in Trade: Sanitary and Phytosanitary Standards. Paper submitted to WTO Meeting on Sanitary and Phytosanitary Standards June 19, World Trade Organization, Geneva.

World Bank (2000). Global Economic Prospects 2001, Washington, DC 